\title{
Occurrence of abnormalities on labral keel of Coronatella monacantha (Cladocera, Anomopoda, Chydoridae) in a population from Ceará, Brazil
}

\author{
Sousa, FDR. ${ }^{a, b *}$,Elmoor-Loureiro, LMA. ${ }^{b *}$ and Souza, MBG. ${ }^{c *}$ \\ aPrograma de Pós-Graduação em Ecologia, Universidade de Brasília - UNB, Brasília, DF, Brazil \\ ${ }^{\mathrm{b}}$ Grupo de Estudos de Ecossistemas Aquáticos, Laboratório de Zoologia, Universidade Católica de Brasília - UCB, \\ QS 7, Lote 1, bloco M, sala 331, CEP 71966-700, Taguatinga, DF, Brazil \\ 'Keratella Estudos e Projetos Ambientais Ltda, Belo Horizonte, MG, Brazil \\ *e-mail: sousa_bio@yahoo.com.br; lourdes@ucb.br; mbiags@gmail.com
}

Received October 6, 2010 - Accepted December 8, 2010 - Distributed August 31, 2011

(With 5 figures)

As a result of agricultural and industrial activities, the contamination of aquatic environments by traceelements has been increasing (Zou and Bu, 1994). This kind of contamination affects water quality directly, and consequently, biological communities, which can cause modifications at an individual level. Martinez et al. (2006) observed deformities in Chironomus tentas larvae when exposed to arsenic. Bioassays have shown that mercury and methylmercury induce abnormalities in the gills of Trichoptera and Ephemeroptera juveniles (Skinner and Bannett, 2007). However, studies on the effects of traceelements on aquatic invertebrates are still incipient.

In a survey of fauna carried out in Ceará State, the occurrence of Alona monacantha Sars 1901, was reported (Sousa et al., 2009). This species has recently been transferred to genus Coronatella (Van Damme et al., 2010).
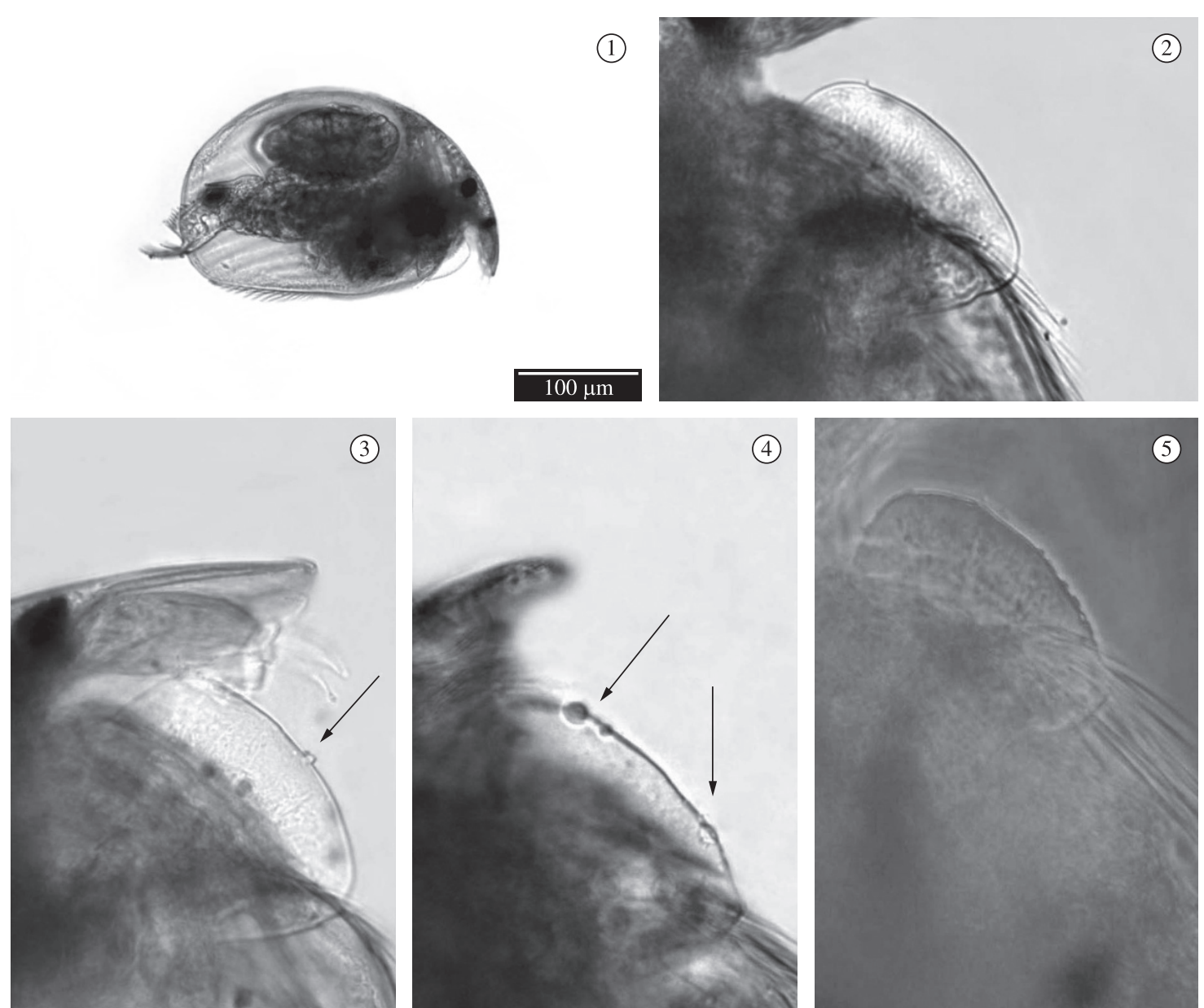

(4)

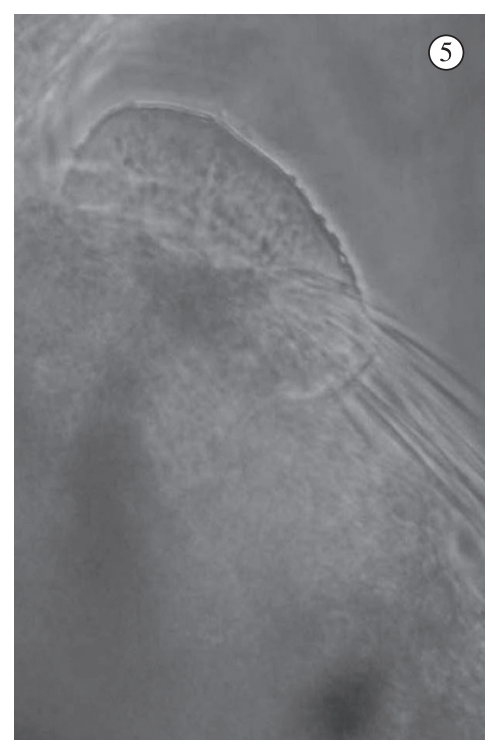

Figures 1-5. Coronatella monacantha (Sars 1901) from Garibas Stream, Ceará, Brazil. 1) adult female; 2) normal labral keel; and 3-5) abnormal labral keel. 
The analysis of Coronatella monacantha specimens revealed the occurrence of some tumor-like modifications on the labral keel (Figures 1-5) of individuals sampled from Garibas Stream (São Gonçalo do Amarante; 3 33' 19" S and $38^{\circ} 52^{\prime}$ '27' W). The sampling was conducted on December $19^{\text {th }}, 2007$, using a plankton net agitated among aquatic vegetation; the sample was preserved in $4 \%$ formalin.

Values of $\mathrm{pH}$, dissolved oxygen and heavy metals dissolved in water were measured, revealing a low dissolved oxygen level $(<2.0 \mathrm{mg} / \mathrm{L})$, acid $\mathrm{pH}(<6.0)$ and high concentrations of total and soluble iron $(>0.6 \mathrm{mg} / \mathrm{L})$. The observed levels of dissolved oxygen and $\mathrm{pH}$ are compatible with freshwater environments with intense iron metabolism (Esteves, 1998). The concentration of iron observed exceeded the limit established by the Brazilian environmental legislation, which is $0.3 \mathrm{mg} / \mathrm{L}$ for freshwater intended for the protection of aquatic organisms and human consumption (Brasil, 2005).

A total of 47 individuals of $C$. monacantha from Garibas Stream were observed, and $27.70 \%$ of these presented modifications on the surface of the labral keel, which was irregular and variable in appearance (Figures 3-5). No morphological alteration was observed in the general shape, carapace, antennas, antennules and post-abdomen.

The occurrence of morphological abnormalities in Cladocera has been occasionally reported (Smirnov, 1996; Shurin and Dodson, 1997; Sinev, 2000). Elmoor-Loureiro (2004) observed modifications in the post-anal spines and claws of Ilyocryptus spinifer, and Zanata et al. (2008) reported abnormalities in the valves of three species of Daphnia. Nevertheless, the causes and consequences of these morphological abnormalities for microcrustaceans have not been properly investigated.

Most trace-elements are fundamental for aquatic organisms' health, such as iron, which is directly involved in the metabolic process. However, exposure to high concentrations of this metal can generate free radicals, which actively participate in organic molecule oxidation, causing cell damage (Buratini and Brandelli, 2006). The high concentrations of total and soluble iron observed in Garibas Stream suggest that this metal could be accumulated in C. monacantha tissues, and consequently, could be responsible for the observed modifications in the labral keel of some individuals. Nevertheless, the actual cause of high concentrations of iron in Garibas Stream is still unknown.

Although the data here are not conclusive about the causes of morphological abnormalities, they suggest that cladocerans are very sensitive to environmental conditions, which corroborates the idea that they are suitable organisms for use as a bioindicator of water quality.

\section{References}

Brasil, Ministério do Meio Ambiente. Conselho Nacional do Meio Ambiente - CONAMA. Resolução CONAMA 357, de 17 de Março de 2005. Brasília: Ministério do Meio Ambiente, CONAMA. 23 p.

BURATINI, SV. and BRANDELLI, A., 2006. Bioacumulação. In ZAGATTO, PA. and BORTOLETTI, E. (Eds.). Ecotoxicologia aquática, princípios e aplicações. São Carlos: Rima. 78 p.

ELMOOR-LOUREIRO, LMA., 2004. Morphological abnormalities in the Cladocera Ilycryoptus spinifer (Apipucos Resevoir, Pernambuco state, Brazil). Brazilian Journal of Biology, vol. 64, no. 1, p. 53-58. http://dx.doi.org/10.1590/S1519-69842004000100007

ESTEVES, FA., 1998. Fundamentos de limnologia. Rio de Janeiro: Interciência. $279 \mathrm{p}$

MARTINEZ, EA., WOLD, L., MOORE, BC., SHAUMLOFFEL, J. and DASGUPTA, N., 2006. Morfological and growt responses in Chironomustentans to arsenic exposure. Environmental Contamination Toxicology, vol. 51, no. 40, p. 529-536. http:// dx.doi.org/10.1007/s00244-005-0308-0

SHURIN, JB. and DODSON, SI., 1997. Sublethal toxic effects of cyanobateria and nonyphenol on environmental sex determination and development in Daphnia.Environmental Toxicology and Chemistry, vol. 16, no. 6, p. 1269-1276.

SINEV, AY., 2000. Postembyonal development of male and abnormal sexual individuals of Alonaaffinis (Leydig, 1860) (Anomopoda, Chydoridade).Hydrobiologia, vol. 437, p. 197-202. http://dx.doi.org/10.1023/A:1026515226055

SKINNER, KM. and BANNETT, JD., 2007. Altered gillmorfology in benthic macroinvertebrates from mercury enriched stream in the Neversink Reservoir Watershed, New York. Ecotoxicology, vol. 16, p. 311-316. http://dx.doi.org/10.1007/s10646-006-0130-0

SMIRNOV, NN., 1996. The Cladocera: the Chydorinae and Sayciinae (Chydoridae) of the world. Amsterdam: SPB Academic Pulbishing. 519p.

SOUSA, FDR., ELMOOR-LOUREIRO, LMA. and SOUZA, MBG., 2009. A contribution to the fauna of Cladocera (Branchiopoda) from Ceará state, Brazil.Nauplius, vol. 17, no. 2, p. 101-105.

VAN DAMME, K., KOTOV, AA. and DUMONT, HJ., 2010. A checklist of names in Alona Baird, 1843 (Crustacea: Cladocera: Chydoridae) and their current status: an analysis of the taxonomy of a lump genus. Zootaxa, vol. 2330, p. 1-63.

ZANATA, LH., ESPÍNDOLA, ELG., ROCHA, O. and PEREIRA, RHG., 2008. Morphologicals abnormalities in Cladocera (Branchiopoda) in cascade of reservoirs in the middle and lower Tietêriver. Brazilian Journal of Biology, vol. 68, no. 3, p. 681-682. http://dx.doi.org/10.1590/S1519-69842008000300028

ZOU, E. and BU, S., 1994. Acute toxicity of Copper, Cadmium, and Zinc to the water flea Moinairrasa (Cladocera). Archives of Contamination and Toxicology, vol. 52, p. 742-748. 